\title{
Valorization of the Peel of Pea: Pisum sativum by Evaluation of Its Antioxidant and Antimicrobial Activities
}

\author{
Fatma Hadrich ${ }^{1}$, Mahdi El Arbi ${ }^{2}$, Maher Boukhris ${ }^{1}$, Sami Sayadi ${ }^{1}$ and Slim Cherif $^{3 *}$ \\ ${ }^{1}$ Laboratoire des Bioprocédés Environnementaux, pôle d'excellence régional (PER, AUF), Centre de Biotechnologie de Sfax, Université de \\ Sfax, B.P. "1177", Sfax 3018, Tunisia. \\ ${ }^{2}$ Institut Superieur de Biotechnologie de Sfax, Route de Soukra km 4, BP 261, 3000 Sfax, Tunisia. \\ ${ }^{3}$ Faculté des Sciences de Gafsa. Campus Universitaire Sidi Ahmed Zarrouk 2112 Gafsa. Université de Gafsa, Tunisia.
}

\begin{abstract}
This study deals with evaluating antioxidant and antimicrobial activities of the peel of pea (Pisum sativum), with particular attention to the content of some bioactive compounds. Total content of polyphenols and flavonoids of Pisum sativum peel extracts, including a crude aqueous extract, a methanolic extract and an ethyl acetate extract was carried out according to the standard methods to assess their corresponding antioxidant activities. The organic solvents extracts antioxidant activities, determined by 1,1-diphenyl-2picrylhydrazyl (DPPH) assay, ferric reducing (FRAP) assay and 2,2 azinobis 3-ethylbenzo-thiozoline-6sulfonic acid (ABTS) assay, were relatively high. The highest activity was found in ethyl acetate extract. The antimicrobial activities of extracts were also assessed. The highest MIC value was occurred with E.Coli $(850$ $\mu \mathrm{g} / \mathrm{ml}$ ) when using ethyl acetate extract. From the results obtained, Pisum sativum peel can be considered as a very good source of health promoting compounds.
\end{abstract}

Key words: valorisation, bark pea, antioxidant, antimicrobial

\section{Introduction}

Edible plants have been reported to have antimicrobial and antioxidant properties for centuries, and indigenous plants have been used in herbal medicine to cure various diseases ${ }^{1)}$. Many kinds of diseases have been treated with herbal remedies since ancient times. Herbal remedies are still being used extensively in many countries. Therefore, research on biologically active extracts and compounds from natural sources has been of great interest to scientists in an attempt to discover new sources for drugs that may be useful in combating infectious diseases ${ }^{2}$. In recent years, there has been a resurgence of interest in evaluating plants possessing antibacterial activities for various diseas$\mathrm{es}^{3,4)}$. A number of studies dealing with antimicrobial screening of extracts plants have been conducted ${ }^{2,3,5)}$. Current research on free radicals confirms the essential role played by rich foods in antioxidants in the prevention of cardiovascular diseases and cancers, neurodegenerative diseases, including Parkinson's, Alzheimer's diseases and inflammation problems of aging cutaneous cells ${ }^{3)}$. Antioxidants are of great importance in terms of oxidative stress prevention, which may result from several degenerative diseases $^{6)}$. Many fruits and vegetables are potentially useful for risk decrease of several chronic diseases, such as coronary heart disease and some cancers ${ }^{7,8}$. These protective effects have been particularly attributed to various antioxidant compounds, such as vitamins $\mathrm{C}$ and $\mathrm{E}$, carotene and polyphenolic compounds ${ }^{9}$. Leaves and fruits of many edible plants has been important for most human cultures $^{1)}$, and especially in the Mediterranean region, making an important contribution to the health of local communities. The leaves of edible plants have been medicinally used in the Mediterranean for its antiseptic, diuretic and laxative effects and also to treat cardiovascular pathologies such as arterial hypertension atherosclerosis and thrombosis ${ }^{10)}$. Bioactive compounds such as polyphenols, aromatic acids, iridoids, monoterpenoids, phenylpropanoids, sterols, triterpenoids and flavonoids present in many leaves and peel edible plants, may explain its pharmacological activity ${ }^{10)}$. Investigations dealing with the richness of useful bioactive molecules from peel vegetables or fruits are still unknown. The peel of pea (Pisumm sativum) has been used extensively in the folk medicine of our country (in Tunisia). In addition, at the author's knowledge, no available informa-

\footnotetext{
*Correspondence to: Slim Cherif, Faculté des Sciences de Gafsa. Campus Universitaire Sidi Ahmed Zarrouk 2112 Gafsa. Université de Gafsa, Tunisia.

E-mail: slimcherif_enis@yahoo.fr

Accepted July 7, 2014 (received for review May 28, 2014)
}

Journal of Oleo Science ISSN 1345-8957 print / ISSN 1347-3352 online

http://www.jstage.jst.go.jp/browse/jos/ http://mc.manusriptcentral.com/jjocs 
tion concerning bioactive compounds from the peel of pea (Pisum sativum) was published. Therefore, the aim of the present work was to evaluate in vitro antimicrobial and antioxidant activities of solvents extracts of peel of pea (Pisum sativum).

\section{Materials and Methods}

\subsection{Reagents}

The 1,1-Diphenyl-2-picrylhydrazyl (DPPH), butylatedhydroxytoluene (BHT) , 2,2 azinobis (3-ethylbenzo-thiozoline6-sulfonic acid) disodium salt (ABTS), 6-hydroxy-2,5,7,8tetra-methylchroman-2-carboxylic acid(Trolox), potassium ferrycianide, ferric chloride and trichloro acetic acid (TCA) were purchased from Sigma Chemical Co. (St. Louis, MO, USA). All other chemicals, namely sodium hydroxide, Folin-Ciocalteu reagent, sodium carbonate and other solvents, were of analytical grade. All solutions were freshly prepared in distilled water and all reagents were of analytical grade.

\subsection{Preparation of extracts}

The compounds of the dried powder of green peel of Pisum sativum were extracted by maceration by adding solvents with increasing polarity: ethyl acetate, methanol and water. Firstly, the powder was extracted by stirring with $250 \mathrm{ml}$ ethyl acetate at $37^{\circ} \mathrm{C}$ for $24 \mathrm{~h}$. The extract was filtered through Whatman filter paper. The filtered was evaporated to dryness under reduced pressure in a rotatory vacuum evaporator. The remaining residues were successively extracted with ethyl acetate, methanol and water under the same conditions. The extracts, from each solvent, were concentrated by rotary evaporator and the water extract was freeze-dried. The dried sample of each extract was weighed. The dried extracts were kept at $4^{\circ} \mathrm{C}$ until further analysis.

\subsection{Total phenolic content (TPC)}

The content of total phenolic compounds in crude extracts was determined using the Folin-Ciocalteu reagent method $^{11)}$ with some modifications. In the test tube, $200 \mu \mathrm{l}$ of each extract was mixed with $500 \mu \mathrm{l}$ of Folin Cioaclteu reagent. Then, $500 \mu \mathrm{l}$ of sodium carbonate solution (75 g/l) was added and the volume was adjusted to $5 \mathrm{ml}$ with distilled water. The mixture was allowed to stand for $30 \mathrm{~min}$ in the dark. The absorbance was measured at $760 \mathrm{~nm}$. Total phenolic contents values were expressed as mg gallic acid equivalents/g extract against a blank.

\subsection{Total flavonoids contents}

Total flavonoids were estimated by using a spectrophotometric assay (colorimetric method previously described ${ }^{12)}$ with slide modifications. Each extract $(50 \mu \mathrm{l})$ was mixed with water $(500 \mu \mathrm{l})$ and $200 \mu \mathrm{l}$ sodium nitrite $(150 \mathrm{~g} / \mathrm{l})$. After 6 min of agitation, $100 \mu$ of aluminium chloride(100 $\mathrm{g} / \mathrm{l}$ ) was added. Then the mixture was incubated for $5 \mathrm{~min}$ before $1 \mathrm{ml}$ of $40 \mathrm{~g} / \mathrm{l} \mathrm{NaOH}$ solution was added. The mixture was diluted to final volume of $2.5 \mathrm{ml}$ with distilled water and mixed throughly. The absorbance was measured at $510 \mathrm{~nm}$. Quercetin was used to make the calibration curve. Total flavonoid content was expressed as mg quercetin equivalent $(\mathrm{QE}) / \mathrm{g}$ dried extract.

\subsection{Antioxidant activity}

\subsubsection{Scavenging of DPPH radicals}

The scavenging effect of phenolic compounds in peel of the green pea crude extracts was monitored as previously described $^{13)}$ with slide modifications. $500 \mu \mathrm{l}$ of extracts at different concentrations $(100-1000 \mu \mathrm{g} / \mathrm{ml})$ was added to test tube containing $375 \mu \mathrm{l}$ of methanol and $125 \mu \mathrm{l}$ of a DPPH methanolic solution ( $0.2 \mathrm{mM})$. The contents were mixed for $1 \mathrm{~min}$, left to stand in the dark at room temperature for $30 \mathrm{~min}$. The BHT was used as a positive control. Scavenging activity of the solution was measured at 517 $\mathrm{nm}$. The assay was replicated three times for each sample. 2.5.2 ABTS assay

ABTS $^{+}$assay was carried out by following the method described $^{14)}$ with some modifications. The stock solution was prepared by mixing $7 \mathrm{mM}$ ABTS and $2.45 \mathrm{mM}$ potassium persulfate in equal volume and allowing to reacting for $12 \mathrm{~h}$ at room temperature in the dark. The solution was then diluted in ethanol to give an absorbance of 0.7 at 734 $\mathrm{nm}$. For the reaction, $3 \mathrm{ml}$ of solution was added to $0.1 \mathrm{ml}$ of the test sample with various concentrations (100-1000 $\mu \mathrm{g} / \mathrm{ml}$ ) and mixed vigorously. The absorbance was measured at $734 \mathrm{~nm}$ after standing for $6 \mathrm{~min}$. The standard curve was obtained using Trolox as standard. Results are expressed in mM Trolox equivalents (TE)/g extract mass. Results are expressed in mM Trolox equivalents (TE)/g extract

2.5.3 Reducing activity

The reducing powers of different extracts were determined by using the followed method ${ }^{15)}$. Sample solutions $(0.5 \mathrm{ml})$ with different concentrations of extracts were mixed with $1.25 \mathrm{ml}$ of $0.2 \mathrm{M}$ phosphate buffer $(\mathrm{pH}$ 6.6) and $1.25 \mathrm{ml}$ of $(10 \mathrm{~g} / \mathrm{l})$ potassium ferricyanide solution. The mixtures were incubated for $30 \mathrm{~min}$ at $50^{\circ} \mathrm{C}$. After incubation, $1.25 \mathrm{ml}$ of $(100 \mathrm{~g} / \mathrm{l})$ trichloroacetic acid was added and the reaction mixtures were centrifuged for $10 \mathrm{~min}$ at $3000 \mathrm{~g}$. A $1.25 \mathrm{ml}$ aliquot of the supernatant from each sample mixture was mixed with $1.25 \mathrm{ml}$ of distilled water and 0.25 $\mathrm{ml}$ of $(1.0 \mathrm{~g} / \mathrm{l})$ ferric chloride solution in a test tube. After a 10 min reaction time, the absorbance was measured at 700 $\mathrm{nm}$. Higher absorbance of the reaction mixture indicated higher reducing power. Values presented are the means of triplicate analyses. 


\subsection{Antimicrobial activity}

2.6.1 Microbial strains

Antimicrobial activities of the peel of pea extracts were tested against four strains of bacteria: Staphylococcus aureus (ATCC 25923), Escherichia coli (ATCC 25922), Pseudomonas aeruginosa (ATCC 27853), Salmonella enterica (ATCC 13883). Antifungal activities were tested using Aspergillus niger and Candida albicans. These strains were provided from Tunisian microorganisms collection (CTM) by the Center of Biotechnology of Sfax, Tunisia.

\subsubsection{Agar diffusion method}

Antimicrobial activity was performed according to the method previously described ${ }^{16)}$. The peels of pea extracts were dissolved at $100 \mathrm{mg} / \mathrm{ml}$ in $100 \%$ dimethyl sulfoxide (DMSO). Culture suspension $(200 \mu \mathrm{l})$ of the tested microorganisms was spread on Muller-Hinton agar and PDA medium, respectively. Sterile filter paper disks (Oxoid, England, $6 \mathrm{~mm}$ diameter)were impregnated with $50 \mu \mathrm{l}$ of the extracts $(100 \mathrm{mg} / \mathrm{ml})$, left to be dried and then placed on the surface of the inoculated agar plates. DMSO served as the negative control while chloramphenicol and gentamycin were used as positive references for bacteria and fungi, respectively. The plates were kept firstly for $2 \mathrm{~h}$ in refrigerator to enable prediffusion of the extracts into the agar and then the Petri dishes were incubatedat $37^{\circ} \mathrm{C}$ for $24 \mathrm{~h}$. Antibacterial activity was determined by measuring the diameter of the clear zones of inhibition in millimeters.

2.6.3 Determination of the minimal inhibitory concentration (MIC)

Minimum inhibitory concentration was determined by micro-well dilution method previously described ${ }^{17)}$. Extracts were dissolved at $100 \mathrm{mg} / \mathrm{ml}$ in $100 \%$ DMSO and then dilution series were prepared in a 96 -well dilution microplate. The chloromphenicol was included as reference in each assay. Extract-free solution was used as a blank control. Each well of the microplates included $40 \mu \mathrm{l}$ of the growth medium, $10 \mu \mathrm{l}$ of the inoculum $\left(10^{6} \mathrm{cfu} / \mathrm{ml}\right)$ and 50 $\mu \mathrm{l}$ of the diluted sample extracts. After that, the microplates were incubated overnight at $37^{\circ} \mathrm{C}$. As an indicator of microorganisms growth, $40 \mu \mathrm{l}$ of p-iodonitrotetrazolium violet (INT) dissolved in water were added to the wells and incubated at $37^{\circ} \mathrm{C}$ for $30 \mathrm{~min}$. The colorless tetrazolium salt acts as an electron acceptor and is reduced to a red-coloured formazan product by biologically active organisms ${ }^{17)}$. The lowest concentration of the extract that produced no visible bacterial growth (no turbidity) when compared with the control was regarded as MIC. The determination of MIC values was done in triplicate.

2.6.4 Inhibition of $\alpha$-amylase

The effect of extracts and fractions on amylase activity was determined by the agar disc diffusion method ${ }^{18)}$. Starch hydrolysis assay was performed on plates composed of $1 \%(\mathrm{w} / \mathrm{v})$ starch dispersed in $1.5 \%$ agar. A bores (3 mm depth, $4 \mathrm{~mm}$ diameter) were made using a sterile boarer and were loaded with $50 \mu \mathrm{l}$ of $\alpha$-amylase from Bacilus subtilis with or without extracts. After incubation at $37^{\circ} \mathrm{C}$ for $72 \mathrm{~h}$, starch plates were stained by flooding with iodine solution $\left(5 \mathrm{mM} \mathrm{I}_{2}\right.$ in $3 \% \mathrm{KI}$ ) for $15 \mathrm{~min}$ at room temperature. Iodine was removed from the plates by washing with distilled water. Amylase activity was determined by observing the zone diameter of hydrolyzed areas around the wells. The $\mathrm{IC}_{50}$ value for $\alpha$-amylase inhibitory activity was determined according to a previous described method ${ }^{19)}$ with some modifications. Fifty microliters of sample were reacted with $250 \mu \mathrm{l}$ of $1 \mathrm{U} / \mathrm{ml} \alpha$-amylase from Bacillus subtilis (Sigma Aldrich) and $450 \mu \mathrm{l}$ of $0.02 \mathrm{M}$ sodium phosphate buffer $(\mathrm{pH} 6.9)$. After pre-incubation at $37^{\circ} \mathrm{C}$ for 10 min, $500 \mu \mathrm{l}$ of a $0.5 \%$ starch solution in $0.02 \mathrm{M}$ sodium phosphate buffer ( $\mathrm{pH} 7.0$ ) were added to each tube. The reaction was incubated at $37^{\circ} \mathrm{C}$ for $20 \mathrm{~min}$ and then stopped with $3 \mathrm{ml}$ of 3,5-dinitrosalicylic acid color reagent. The test tubes were then incubated in a heating block for 5 min and then the absorbance was measured at $540 \mathrm{~nm}$.

\section{Results and Discussion}

\subsection{Extraction yield and total phenolic contents}

The yields values obtained for the different extracts were resumed in the Table 1. The results showed that the yield of extractable components relative to the weight of dried plant material ranged from 3.75\% (ethyl acetate extraction) to $33.5 \%$ (methanol extraction) (Table 1). This

Table 1 Extract yield and total phenolic and flavonoid contents from the peel of pea extracts.

\begin{tabular}{lccc}
\hline \multicolumn{1}{c}{ Extracts } & Yield (\%) & $\begin{array}{c}\text { Phenolic } \\
\text { (mg GE/g extract) }\end{array}$ & $\begin{array}{c}\text { Flavonoids } \\
\text { (mg QE/g extract) }\end{array}$ \\
\hline Ethyl acetate & $3.75 \pm 0.3$ & $67.5 \pm 1.0$ & $22 \pm 0.9$ \\
Methanol & $33.5 \pm 2.3$ & $62.5 \pm 0.8$ & $3.5 \pm 0.05$ \\
Water & $21.22 \pm 1.3$ & $8.75 \pm 0.4$ & $0.5 \pm 0.05$ \\
\hline
\end{tabular}

Values are expressed as mean \pm standard deviation of three independent determinations. 
Table $2 \mathrm{IC}_{50}(50 \%$ concentration of inhibition for radical scavenging activity) values express the concentration in $\mu \mathrm{g} / \mathrm{ml}$ and $\mathrm{mmol}$ TEAC/ml for DPPH and ABTS, respectively for each sample.

\begin{tabular}{lcc}
\hline \multicolumn{1}{c}{ Extracts } & $\begin{array}{c}\mathrm{IC}_{50} \text { on DPPH radical } \\
(\mathrm{mg} / \mathrm{ml})\end{array}$ & $\begin{array}{c}\mathrm{IC}_{50} \text { on ABTS radical } \\
(\mu \mathrm{mol} \mathrm{TEAC} / \mathrm{mg})\end{array}$ \\
\hline Ethyl acetate & $0.350 \pm 0.02$ & $9.6 \pm 1.1$ \\
Methanol & $0.650 \pm 0.05$ & $1.9 \pm 0.5$ \\
Water & $>1$ & \\
BHT & $0.900 \pm 0.01$ & \\
\hline
\end{tabular}

BHT was used as positive control. Values are mean \pm SD of triplicates

result is in contrast with the report of authors ${ }^{20)}$ who showed that water is the most suitable solvent for extraction of phenolic compounds from Pleurotus citrinopileatus. Whereas, it differed from the authors reports ${ }^{21,22)}$ which proved that the methanol is the most suitable solvent for extraction of phenolic compounds. Total flavonoid content of the ethyl acetate, methanol, and water fractions were $22 \pm 0.9,3.5 \pm 0.05$ and $0.5 \pm 0.05 \mathrm{mg} / \mathrm{g}$ of dry weight of extract, respectively. Similarly, the amount of total phenolic content of the ethyl acetate, methanol, and water fractions were $67.5 \pm 1.0,62.5 \pm 0.8$, and $8.75 \pm 0.4$ $\mathrm{mg} / \mathrm{g}$ of dry weight of extract, respectively. As shown in Table 1, Total flavonoid and phenolic contents in the ethyl acetate fraction were the highest among the three fractions. These results are in good agreement with previous studies on other plant materials, like Cinnamomumos mophloeum twigs ${ }^{23)}$.

\subsection{Antioxidant activity}

3.2.1 Antioxidant activity using DPPH and ABTS assays

The scavenging ability of BHT and various extracts is shown in Table 2. It can be observed that the methanol and ethyl acetate fractions exhibited stronger scavenging ability at all the tested concentrations. The methanol fraction showed a slightly weaker scavenging ability. The water fraction exhibited poor scavenging. In fact, the $\mathrm{IC}_{50}$ was equivalent to $350 \mu \mathrm{g} / \mathrm{ml}$ and $650 \mu \mathrm{g} / \mathrm{ml}$ for ethyl acetate and methanol extracts, respectively. BHT showed the highest scavenging ability (Table 2).

ABTS is one of the radicals generally used for testing the preliminary radical scavenging activity of a compound or plants extracts. The $\mathrm{ABTS}^{+}$, generated from oxidation of ABTS by potassium persulfate, is presented as an excellent tool for determining the antioxidant activity of hydrogendonating anti-oxidants (scavengers of aqueous phase radicals $)^{24)}$. The ABTS $^{+}$scavenging ability reported as Trolox equivalent antioxidant capacity (TEAC) was presented in Table 2. The results revealed that the $\mathrm{IC}_{50}$ of ethyl acetate extract $(9.6 \pm 1.1 \mu \mathrm{mol}$ TEAC/g $)$ was higher than that of the methanol extract $(1.9 \pm 0.5 \mu \mathrm{mol} \mathrm{TEAC} / \mathrm{g})$. This result is due to the richness of ethyl acetate and methanol extracts with antioxidants compounds comparing to the water extract. There's no report about the antioxidant activity of peel of green pea, but it was well demonstrated that their seeds exhibited high radical scavenging activity ${ }^{25)}$.

3.2.2 Ferric reducing/antioxidant power(FRAP)

The reducing power assay is often used to evaluate the ability of natural antioxidant to donate an electron or hydrogen $^{26)}$. Different studies have reported that there is a direct correlation between antioxidant activities and reducing power of certain bioactive compounds. It has been widely accepted that the higher the absorbance at $700 \mathrm{~nm}$, the greater is the reducing power. In this study, the ability of the peel pea extracts, and BHT as a positive control, to reduce $\mathrm{Fe}^{3+}$ to $\mathrm{Fe}^{2+}$ was determined. As shown in Fig. 1, the reducing capacity of peel of pea extracts differed significantly in their activity. In fact, the reducing powers of BHT, methanol, water and ethyl acetate extracts, at a concentration of $2 \mathrm{mg} / \mathrm{ml}$, were $1.32,0.36$ and 1.84 , respectively. Previous studies showed that ethanol 70\% was the best solvent for FRAP antioxidant assay of yellow pea and green

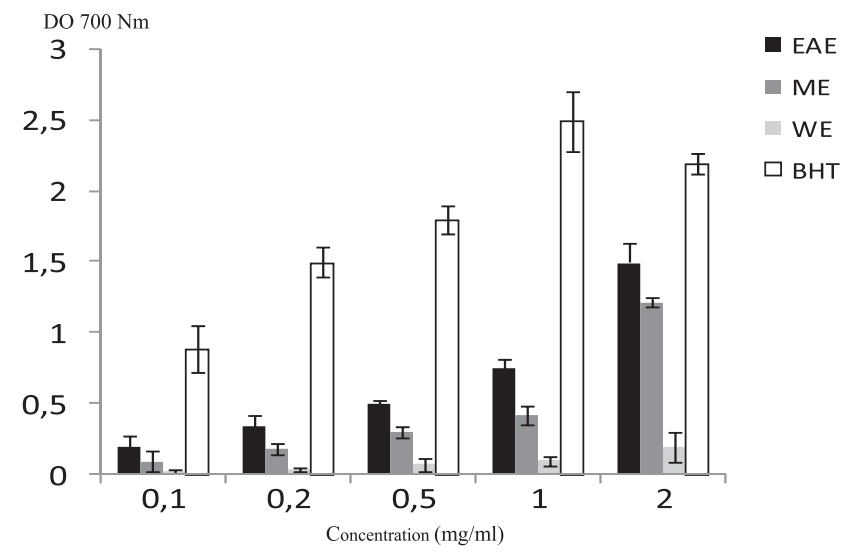

Fig. 1 Reducing power of peel of pea extracts measured with ethyl acetate (EAE), methanol (ME) and water extracts (WE). BHT was used as positive control. Values are means $\pm \operatorname{SD}(n=3)$. 
pea $^{27)}$.

\section{$3.3 \alpha$-Amylase inhibition activity}

The $\alpha$-amylase is an important enzyme in the digestive system and catalyzes the initial step in the hydrolysis of starch, which is a principal source of glucose in the diet ${ }^{28)}$. The control of this enzyme is an important factor in post prandial hyperglycemia, which is linked to the onset of type 2 DM. The inhibitory effects of the extracts derived from peel pea extracts on $\alpha$-amylase were investigated and the results are shown in Fig. 2. Whereas, the ethyl acetate

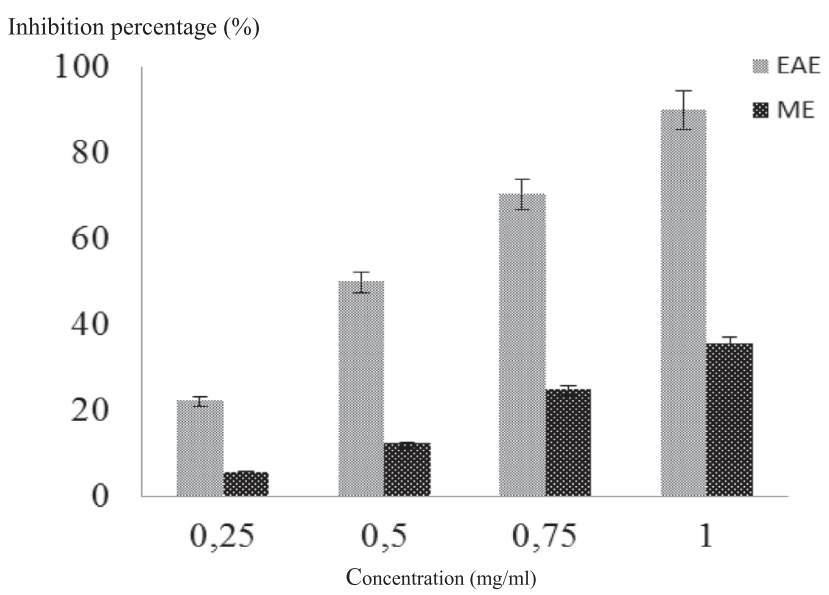

Fig. $2 \alpha$-amylase inhibition of peel of pea extracts. Various concentrations of extracts were incubated for 10 min with $\alpha$-amylase solution. After pre-incubation, $1 \%$ starch solution was added to each tube. The reaction mixtures were then incubated at $25^{\circ} \mathrm{C}$ for $10 \mathrm{~min}$. The reaction was stopped with $1.0 \mathrm{ml}$ of dinitrosalicylic acid color reagent. extract showed significantly higher inhibitory activity compared to control untreated. In fact, the inhibitory effects of ethyl and methanol extracts were $90 \% \pm 4.5$ and $35.3 \% \pm$ 2.12 , respectively, at $1 \mathrm{mg} / \mathrm{ml}$ which was the highest concentration tested. Consequently, we can conclude that ethyl acetate extract which contain a large amounts of flavonoids and phenolic compounds exhibit $\alpha$-amylase inhibition activity. The results of our experiments seemed to agree with finding which was reported that some flavonoids, such as rutin, myricetin, kaempferol and quercetin, have been previously reported to inhibit $\alpha$-glucosidase and $\alpha$-amylase. These flavonoids exhibit both hypoglycemic and antioxidant effects in diabetic animals ${ }^{29,30)}$. This result is in contrast with those of previous studies, which have demonstrated that plant-derived phenolic phytochemicals have lower $\alpha$-amylase inhibitory activity and stronger inhibition potential against $\alpha$-glucosidase ${ }^{31-33)}$.

\subsection{Antibacterial activity}

Many studies have shown the antibacterial and antifungal activity of protein extracted from the seeds of pea ${ }^{27)}$. Literature strongly supports that plant with high polyphenols and flavonoids contents display antimicrobial properties. The antibacterial activity of peel pea extracts was tested against Gram-positive ( $S$. aureus) and Gram-negative (E. coli, P. aeruginosa and $S$. entertica) bacteria. As can be seen in Table 3, the ethyl acetate extract was found to be the most effective and exhibited different degrees of antibacterial activity against most of the Gram-positive and Gram negative bacteria tested, followed by the methanol extract. The most susceptible bacteria for the ethyl acetate extract was $P$. aeruginosa, with MIC values of $350 \mu \mathrm{g} / \mathrm{ml}$. Whereas, the highest MIC value was occurred with $E$. coli $(850 \mu \mathrm{g} / \mathrm{ml})$ when using ethyl acetate extract.

Table 3 Antimicrobial activity of the peel of pea extracts (inhibition zone diameter $(\mathrm{mm})$ and minimum inhibitory concentration (MIC) $(\mu \mathrm{g} / \mathrm{ml})$.

\begin{tabular}{|c|c|c|c|c|c|c|c|c|}
\hline \multirow{2}{*}{ Microorganisms } & \multicolumn{4}{|c|}{ Inhibition zone diameter (mm) } & \multicolumn{4}{|c|}{$\operatorname{MIC}(\mu \mathrm{g} / \mathrm{ml})$} \\
\hline & EAE & $\mathrm{ME}$ & WE & Standards ${ }^{\mathrm{a}}$ & EAE & $\mathrm{ME}$ & WE & Standards ${ }^{\mathrm{a}}$ \\
\hline \multicolumn{9}{|l|}{ Bacterial strains } \\
\hline P. aerugionosa & $17 \pm 1.0$ & $7 \pm 0.5$ & ND & $18 \pm 1.0$ & $350 \pm 10$ & $750 \pm 30$ & ND & $15 \pm 0.05$ \\
\hline S. aureus & $16 \pm 0.5$ & $8.0 \pm 1.0$ & ND & $22 \pm 1.5$ & $625 \pm 20$ & $1000 \pm 10$ & ND & $10 \pm 0.02$ \\
\hline E. coli & $19 \pm 1.0$ & ND & ND & $20 \pm 1.5$ & $850 \pm 30$ & $>1000$ & ND & $20 \pm 0.02$ \\
\hline S. enterica & $15 \pm 0.5$ & ND & ND & $16 \pm 0.5$ & $450 \pm 10$ & $600 \pm 20$ & ND & \\
\hline \multicolumn{9}{|l|}{ Fungal starins } \\
\hline C. albicans & $16 \pm 1.0$ & $13 \pm 0.5$ & ND & $18 \pm 1.0$ & $450 \pm 20$ & $750 \pm 20$ & ND & $18 \pm 0.5$ \\
\hline A. niger & $13 \pm 1.0$ & $6.0 \pm 0.5$ & ND & $15 \pm 0.5$ & $550 \pm 10$ & NT & ND & $30 \pm 1.0$ \\
\hline
\end{tabular}

EAE: ethyl acetate extract, ME: methanol extract, WE: water extract

ND: not detected

${ }^{a}$ Chloramphenicol and gentamycin were used as standard antibiotics for bacteria and fungi, respectively. 


\subsection{Antifungal activity}

The antifungal activities of the selected plant extracts were tested against two kinds of fungal species, namely $C$. albicans representing the yeast modal and $A$. niger representing filamentous fungus. The results of this activity are presented in Table 3. Among the solvent extracts tested, the ethyl acetate and methanol extract showed an inhibition activity against $C$. albicans with MIC values of 450 and $750 \mu \mathrm{g} / \mathrm{ml}$, respectively. However only the ethyl acetate extract displayed activity against $A$. niger. In this case, Heisey and Gorham have reported that pathogenic fungi are more resistant to plant extracts than pathogenic bacteria. This fact, based on our results was not so confirmed.

\section{Conclusion}

In conclusion, our investigation indicated that the peel of pea extracts represent a source of active compounds essentially phenols and flavonoids with antioxidant activity and an in vitro $\alpha$-amylase inhibitory activity. Also, the ethyl acetate extract showed an antibacterial and antifungal activity. Further studies should be completed to purify the active compounds. Therefore, the present study suggests a basis for the possible use of peel of pea extracts as a traditional folk medicine.

\section{References}

1) Shahin, S. A.; Kasoju, N.; Luthra, A.; Singh, A.; Sharanabasava, H.; Sahu, A.; Bora, U. Indian medicinal herbs as sources of antioxidants. Food Reas. Inter. 41, 1-15 (2008).

2) Hadrich, F.; Cherif, S.; Gargouri, Y. T.; Sayari, A. Antioxidant and lipase inhibitory activities and essential oil composition of pomegranate peel extracts. J. Oleo Sci. 63, 515-525 (2014).

3) Sakunpak, A.; Panichayupakaranant, P. Antibacterial activity of Thai edible plants against gastrointestinal pathogenic bacteria and isolation of a new broad spectrum antibacterial polyisoprenylated benzophenone chamangone. Food Chem. 130, 826-831 (2012).

4) Zaouali, Y.; Bouzaine, T.; Boussaid, M. Essencial oils composition in two Rosamarinus officinalis L. varieties and incidence for antimicrobial and antioxidant activities. Food Chem. Toxicol. 48, 3144-3152(2010).

5) Zouari, S.; Ketata, M.; Boudhrioua, N.; Ammar, E. Allium roseum $\mathrm{L}$. volatile compounds profile and antioxidant activity for chemmotype discrimination-case study of the wild plant of $\operatorname{Sfax}$ (Tunisia). Indust. Crop Prod. 41, 172-178(2013).

6) Jacob, J. K.; Hakimuddin, F.; Paliyath, G.; Fisher, H. Antioxidant and antiproliferative activity of polyphe- nols in novel high-polyphenol grape lines. Food Reas. Inter. 41, 419-428(2008).

7) Bhupathiraja, S. N.; Tucker, K. L. Coronary heart disease prevention: Nutrients, foods and dietary patterns. Clinica Chimica Acta 412, 1493-1514(2011).

8) Gorinstein, S.; Caspsi, A.; Libman, I.; Katrich, E.; Trakhtenberg, S. Preventive effects of diets supplemented with sweetive fruits in hypercholestrerolemic patients suffering from coronary artery disease. Preventive Medicine 38, 841-847 (2004).

9) Rehman, A.; Collis, C. S.; Yang, M.; Kelly, M.; Diplock, A. T.; Halliwell, B.; Evans, C. The effects of Iron and vitamin $\mathrm{C}$ co-supplementation on oxidative damage to DNA in healthy volunteers. Biochem. Biophys. Reas. Comm. 246, 293-298(1998).

10) Nguelefack-Mbungo, P. E.; Nguelefack, T. B.; Dongmo, A. B.; Afkir, S.; Azebaze, A. G. B.; Dimo, T.; Leyssyer, A.; Kamanyi, A.; Ziyyat, A. Anti- hypertensive effects of the methanol/methylene chloride stem bark extract of Mammea Africana in L-NAME-induced hypertensive rats. J. Ethnopharmacol. 117, 446-450 (2008).

11) Djeridane, A.; Yousfi, M.; Nadjemi, B.; Boutassouna, D.; Stocher, P. Vidal, N. Antioxidant activity of some Algerian medicinal plants extracts containing phenolic compounds. Food Chem. 97, 654-660 (2006).

12) Kim, D. O.; Jeong, S. W.; Lee, C. Y. Antioxidant capacity of phenolic phytochemicals from various cultivars of plums. Food Chem. 81, 321-326 (2003).

13) Mohsen, S. M.; Ammar, A. S. M. Total phenolic contents and antioxidant activity of corn tassel extracts. Food Chem. 112, 595-598(2009).

14) Cai, Y.; Luo, Q.; Sun, M.; Corke, H. Antioxidant activity and phenolic compounds of 112 traditional Chinese medicinal plants associated with anticancer. Life Sci. 74, 2157-2184 (2004).

15) Yildirim, A.; Mavi, A.; Kara, A. A. Determination of antioxidant and antimicrobial activities of Rumex crispus L. extracts. J. Agric. Food Chem. 49, 4083-4089 (2001).

16) Berghe, V. A.; Vlietinck, A. J. Screening methods for antibacterial and antiviral agents from higher plants. Meth. Plant Biochem. 6, 47-68(1991).

17) Eloff, J. N. A sensitive and quick microplate method to determine the minimal inhibitory concentration of plant extracts for bacteria. Planta Med. 64, 711-713 (1998).

18) Cha, W. S.; Ju, I. S.; Yun, D. H.; Chun, S. S.; Kim, J. H.; Cho, Y. J. Biological activity of extracts from cherry sage (Salvia officinalis L.). Kor. J. Life Sci. 19, 390396 (2009).

19) Kwon, G. J.; Choi, D. S.; Wang, M. H. Biological activities of hot water extracts from Euonymus alatus leaf. Kor. J. Food Sci. Tech. 39, 569-574(2007).

20) Lee, Y. L.; Huang, G. W.; Liang, Z. C.; Mau, G. L. Anti- 
oxidant properties of three extracts from Pleurotus citrinopileatus. LWT-Food; Sci. Technol. 40, 823-33 (2007).

21) Hertog, M. G. L.; Hollman, P. C. H.; Van de Putte, B. Content of potentially anticarcinogenic flavonoids of tea infusions, wines, and fruit juices. J. Agric. Food Chem. 41, 1242-1246 (1993).

22) Yen, G.; Wu, S.; Duh, P. Extraction and identification of antioxidant components from the leaves of mulberry(Morusalba L.). J. Agric. Food Chem. 44, 16871690 (1996).

23) Chua, M. T.; Tung, Y. T.; Chang, S. T. Antioxidant activities of ethanolic extracts from the twigs of Cinnamomumos mophloeum. Biores. Technol. 99, 1918-1925 (2008).

24) Leong, L. P.; Shui, G. An investigation of antioxidant capacity of fruits in Singapore markets. Food Chem. 76, 69-75 (2002).

25) Nithiyanantham, S.; Selvakumar, S.; Siddhuraju, P. Total phenolic content and antioxidant activity of two different solvent extracts from raw and processed legumes, Cicera rietinum L. and Pisum sativum L. J. Food Compos. Analysis 27, 52-60 (2012).

26) Shimada, K.; Fujikawa, K.; Yahara, K.; Nakamura, T. Antioxidative properties of xanthum on the autoxidation of soybean oil in cyclodextrin emulsion. J. Agric. Food Chem. 40, 945-948(1992).

27) Xu, B. J.; Chang, S. K. C. A Comparative Study on Phenolic Profiles and Antioxidant Activities of Legumes as Affected by Extraction Solvents. J. Food Sci. 72, S159-S166 (2007).
28) Tarling, C. A.; Woods, K.; Zhang, R.; Brastianos, H. C.; Brayer, G. D.; Andersen, R. J.; Withers, S. G. The search for novel human pancreatic amylase inhibitors: high-through put screening of terrestrial and marine natural product extracts. Chem. Bio. Chem. 9, 433438(2008).

29) Kamalakkannan, N.; Prince, P. S. M. Rutin improves the antioxidant status in streptozotocin-induced diabetic rat tissues. Mol. Cell. Biochem. 293, 211-219 (2006).

30) Wang, H.; Du, Y. J.; Song, H. C. $\alpha$-Glucosidase and $\alpha$-amylase inhibitory activities of guava leaves. Food Chem. 123, 6-13(2010).

31) Apostolidis, E.; Kwon, Y. I.; Shetty, K. Potential of cranberry-based herbal synergies for diabetes and hypertension management. Asia. Pac. J. Clin. Nutr. 15, 433-441 (2006).

32) Kwon, Y. I.; Apostolidis, E.; Shetty, K. In vitro studies of eggplant (Solanum melongena) phenolics as inhibitors of key enzymes relevant for type 2 diabetes and hypertension. Bioresour. Technol. 99, 2981-2988 (2008).

33) Apostolidis, E.; Lee, C. In vitro potential of Ascophyllum nodosum phenolic antioxidant-mediated $\alpha$-glucosidase and $\alpha$-amylase inhibition. J. Food Sci. 75, 97-102 (2010).

34) Heisey, R. M.; Gorham, B. K. Antimicrobial effects of plant extract on Streptococcus mutans, Candida albicans, Trichophyton rubrum and other microorganisms. Lett. Appl. Microbiol. 14, 136-139 (1992). 